\title{
Parametric Studies for Vertical Axis Wind Turbine Simulations
}

\author{
Linda Gulbe ${ }^{1}$, Normunds Jekabsons ${ }^{2}$, Agris Traskovs ${ }^{3}{ }^{1-3}$ Ventspils University College
}

\begin{abstract}
Efficiency of the vertical axis wind turbine depends on turbine design. Wind tunnel experiments, usually performed for evaluation of turbine design, are expensive in comparison with CFD simulations. Although purely numeric, CFD models critically depend on a large set of parameters, which varies from mesh size to numerical schemes and models of turbulence. The aim of the presented research is to evaluate the critical ranges of these parameters for a practically applicable turbine design.
\end{abstract}

Keywords - convergence of the model, mesh size, models of turbulence, numerical approximation schemes

\section{INTRODUCTION}

Decreasing amounts of non-renewable energy resources and increasing environmental pollution have lead to the development of wind energy use. Horizontal axis wind turbines are leaders in the field of wind energy; however these devices must be placed in specially chosen places which present significant opportunities to develop the use of vertical axis wind turbines (VAWT) in urban areas. VAWTs are able to work in more complex wind conditions, make less noise, better fit in the landscape and use smaller amounts of material resources.

Efficiency of the VAWT depends on turbine design which can be optimized by the shape and angles of the blades or additional constructions. Wind tunnel experiments, usually performed for the evaluation of various turbine designs, are expensive. An alternative for these experiments is CFD (Computational Fluid Dynamics) simulations. CFD simulations combine advantages of theoretical and experimental approaches, but depend crucially on a large set of parameters like mesh size, numerical schemes and models of turbulence.

There are many properties on how to evaluate numerical solution, for example, stability, consistency, convergence and accuracy. The aim of this study is to evaluate the impact of mesh size, numerical schemes and turbulence models to the convergence for a practically applicable turbine design. The evaluating of convergence needs an extensive experimental approach, and it is an extremely important part of the research before performing further calculations to acquire the performance efficiency of the VAWT's design. Parameters were tested on two-dimensional test case. Despite the twodimensional approach, the calculation complexity was high enough to necessitate a multi-processor system: 4 core $3 \mathrm{GHz}$ Intel Xenon system with MPI support was employed. The OpenFoam CFD toolbox solver for incompressible turbulent flow with several Reynolds average $\mathrm{k}-\varepsilon$ turbulence models was also used.
The paper proceeds as follows: in the second chapter, the comparison between different $\mathrm{k}-\varepsilon$ models is given, the third chapter is devoted to description of the model and mesh properties, in the fourth chapter, various numerical schemes for approximation of convective terms are described and compared, and the reliability of results are described in the fifth chapter. Conclusions on the research's accomplishments and suggestions are summarised in the last part.

\section{GOVERNING EQUATIONS AND TURBULENCE MODELS}

Air flow is assumed to be turbulent and incompressible in this research. One approach on how to approximate turbulent flows is the Reynolds averaged Navier - Stokes (RANS) equations. According to this methodology, flow variables, like velocity and pressure, are decomposed into a mean and a fluctuating part. The RANS mass conservation equation and impulse conservation equations are given by:

$$
\begin{gathered}
\frac{\partial u_{i}}{\partial x_{i}}=0 \\
u_{j} \frac{\partial u_{i}}{\partial x_{j}}=\frac{1}{\rho} \frac{\partial p}{\partial x_{i}}+v \frac{\partial^{2} u_{i}}{\partial x_{j} \partial x_{j}}+\frac{\partial}{\partial x_{j}}\left(-\overline{u_{\imath}^{\prime} u_{j}^{\prime}}\right),
\end{gathered}
$$

where $u_{i}$,- mean velocity component in $i$ direction; $p$ - mean pressure, $v$ - kinematic viscosity; $u_{i}^{\prime}$ - fluctuating part of velocity in $i$ direction; $\overline{u_{\imath}^{\prime} u_{\jmath}{ }^{\prime}}-$ time averaging over velocity fluctuations [2],[8].

In the two-dimensional case, (1) and (2) can be rewritten:

$$
\frac{\partial u_{x}}{\partial x}+\frac{\partial u_{y}}{\partial y}=0
$$

$u_{x} \frac{\partial u_{x}}{\partial x}+u_{y} \frac{\partial u_{x}}{\partial y}=-\frac{1}{\rho} \frac{\partial p}{\partial x}+v\left(\frac{\partial^{2} u_{x}}{\partial x^{2}}+\frac{\partial^{2} u_{x}}{\partial y^{2}}\right)-\frac{\partial \overline{u_{x}^{\prime} u_{x^{\prime}}}}{\partial x}-\frac{\partial \overline{u_{x}^{\prime} u_{y^{\prime}}}}{\partial y}$

$u_{x} \frac{\partial u_{y}}{\partial x}+u_{y} \frac{\partial u_{y}}{\partial y}=-\frac{1}{\rho} \frac{\partial p}{\partial y}+v\left(\frac{\partial^{2} u_{y}}{\partial x^{2}}+\frac{\partial^{2} u_{y}}{\partial y^{2}}\right)-\frac{\partial \overline{u_{y}^{\prime} u_{x^{\prime}}}}{\partial x}-\frac{\partial \overline{u_{y}^{\prime} u_{y^{\prime}}}}{\partial y}$

The left sides of the impulse conservation equations (2), (4) are deemed convective terms, and they will be necessary in the fourth chapter where numerical approximation schemes are discussed. Terms $\overline{-u_{\imath}^{\prime} u_{\jmath}{ }^{\prime}}$ represent Reynolds stresses and can be modelled by different turbulence models. This research focuses only on the most popular $k-\varepsilon$ turbulence model. Two improved $k-\varepsilon$ models, besides the standard one, are tested to investigate changes in convergence. 


\section{A. Standard $k-\varepsilon$ turbulence model}

According to the Boussinesq (turbulent - viscosity) hypothesis, Reynolds stresses [5] are approximated with

$$
\overline{u_{\imath}^{\prime} u_{\jmath}^{\prime}}=\frac{2}{3} k \delta_{i j}-v_{T}\left(\frac{\partial u_{i}}{\partial x_{j}}+\frac{\partial u_{j}}{\partial x_{i}}\right)
$$

where $k$ - turbulence kinetic energy; $v_{T}$ - turbulent viscosity.

Standard $\mathrm{k}-\varepsilon$ turbulence model is a two-equation model, which solves transport equations for the turbulence kinetic energy $k$

$$
u_{j} \frac{\partial k}{\partial x_{j}}=\nabla \cdot\left(\frac{\nu_{T}}{\sigma_{k}} \nabla k\right)+P-\varepsilon
$$

and dissipation rate $\varepsilon$

$$
u_{j} \frac{\partial \varepsilon}{\partial x_{j}}=\nabla \cdot\left(\frac{\nu_{T}}{\sigma_{\varepsilon}} \nabla \varepsilon\right)+C_{1 \varepsilon} \frac{P \varepsilon}{k}-C_{2 \varepsilon} \frac{\varepsilon^{2}}{k},
$$

where $v_{T}=C_{\mu} \frac{k^{2}}{\varepsilon}, P=v_{T}\left(\sqrt{2 S_{i j} S_{i j}}\right)^{2}$ and $S_{i j}=\frac{1}{2}\left(\frac{\partial u_{i}}{\partial x_{j}}+\frac{\partial u_{j}}{\partial x_{i}}\right)$.

The model constants for standard and other models are summarised in Table I.

\section{B. $R N G k-\varepsilon$ turbulence model}

The RNG $\mathrm{k}-\varepsilon$ model has renormalized Navier - Stokes equations to take into account the effects of smaller scales of motion [5], [11], [12]. The RNG model includes analytical expression for turbulent Prandtl numbers, effective viscosity and the effect of swirl on turbulence. The RNG model is believed to be more precise and reliable than the standard one. The turbulence kinetic energy equation is the same as in standard $k-\varepsilon$ model, except the dissipation rate equation differs:

$$
u_{j} \frac{\partial \varepsilon}{\partial x_{j}}=\nabla \cdot\left(\frac{v_{T}}{\sigma_{\varepsilon}} \nabla \varepsilon\right)+C_{1 \varepsilon} \frac{P \varepsilon}{k}-C_{2 \varepsilon}^{*} \frac{\varepsilon^{2}}{k},
$$

where

$$
\begin{gathered}
C_{2 \varepsilon}^{*}=C_{2 \varepsilon}+\frac{C_{\mu} \eta^{3}\left(1-\frac{\eta}{\eta_{0}}\right)}{1+\beta \eta^{3}}, \\
\eta=\frac{\sqrt{2 S_{i j} S_{i j}} k}{\varepsilon}
\end{gathered}
$$

\section{Realizable $k-\varepsilon$ turbulence model}

The Realizable $k-\varepsilon$ model dissipation rate equation is based on the dynamic equation of the mean-square velocity fluctuation at a large turbulent Reynolds number [5], [11], [12]. It contains a new formulation for turbulent viscosity and the dissipation rate equation is modified as follows:

$$
u_{j} \frac{\partial \varepsilon}{\partial x_{j}}=\nabla \cdot\left(\frac{v_{T}}{\sigma_{\varepsilon}} \nabla \varepsilon\right)+C_{1} \mathrm{~S} \varepsilon-\mathrm{C}_{2} \frac{\varepsilon^{2}}{k+\sqrt{v \varepsilon}}+\mathrm{C}_{1 \varepsilon} \frac{\varepsilon}{\mathrm{k}}
$$

where $C_{1}=\max \left[0.43, \frac{\eta}{\eta+5}\right], \eta=S \frac{k}{\varepsilon}, S=\sqrt{2 S_{i j} S_{i j}}$.

For the rest of the model, please refer [11].
TABLE I

MODEL CONSTANTS

\begin{tabular}{|l|c|}
\hline & $C_{\mu}=0.09$ \\
Standard k $-\varepsilon$ & $C_{1 \varepsilon}=1.44$ \\
& $C_{2 \varepsilon}=1.92$ \\
& $\sigma_{\varepsilon}=1.3$ \\
& $\sigma_{k}=1.0$ \\
\hline Realizable k - $\varepsilon$ & $C_{1 \varepsilon}=1.44$ \\
& $C_{2}=1.9$ \\
& $\sigma_{k}=1.0$ \\
& $\sigma_{\varepsilon}=1.2$ \\
$A_{0}=4.0$ \\
\hline RNG k - $\varepsilon$ & $C_{\mu}=0.0845$ \\
& $C_{1 \varepsilon}=1.42$ \\
& $C_{2 \varepsilon}=1.68$ \\
& $\sigma_{k}=0.71942$ \\
& $\sigma_{\varepsilon}=1.3$ \\
& $\eta_{0}=4.38$ \\
& $\beta=0.012$ \\
\hline
\end{tabular}

\section{Results}

Torque value convergence in Fig. 1 shows that the standard $k-\varepsilon$ model converges faster than the other two turbulence models. However, these results differ slightly from the RNG and Realizable $k-\varepsilon$ models. A real wind tunnel experiment would be necessary to evaluate which model gives results which best suit the real situation. A more refined mesh could improve the convergence of RNG and Realizable $k-\varepsilon$ models, but for the moment this is out of the scope of this research.

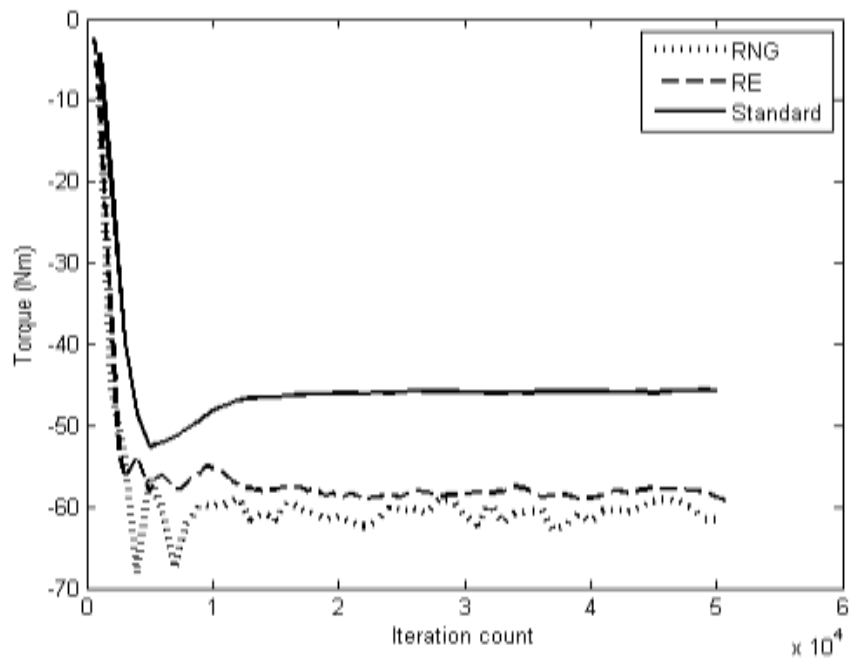

Fig. 1. Comparison of torque values between RNG, Realizable and Standard $\mathrm{k}-\varepsilon$ models during the calculations.

Figures 2, 3 and 4 show results for pressure and turbulence kinetic energy contour plots. The greatest differences are demonstrated by the RNG $\mathrm{k}-\varepsilon$ model. This model causes higher turbulence. Due to the periodical boundary conditions on the free surface boundary, the flow is constrained in $x$ direction. This evidently leads to distortion of the air flow behind the rotor. Wider and more refined mesh would be recommended for more exact studies. 


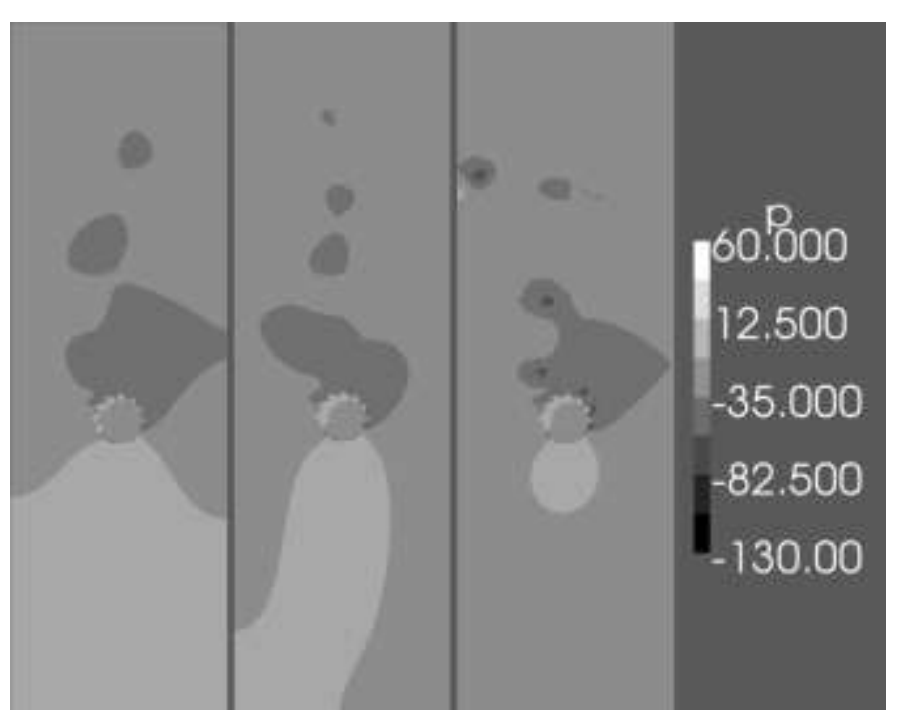

Fig. 2. Pressure contour plot of Standard, Realizable and RNG $k-\varepsilon$ turbulence models (presented in sequence of images).

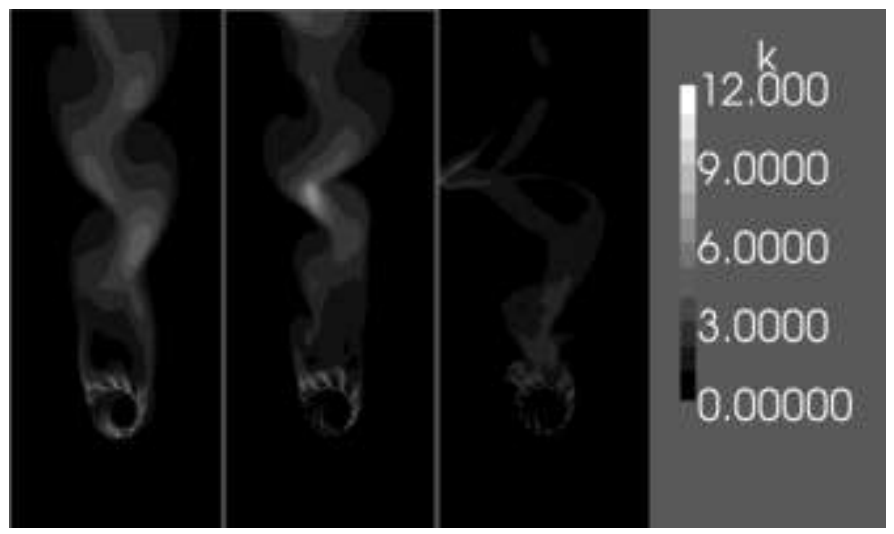

Fig. 3. Turbulence kinetic energy contour plot of Standard, Realizable and $\mathrm{RNG} \mathrm{k}-\varepsilon$ turbulence models (presented in sequence of images).

Pressure contour plots with velocity vectors are shown in Fig. 5. The RNG $k-\varepsilon$ model, again, shows the greatest differences.

\section{GEOMETRY OF THE MODEL AND MESH PROPERTIES}

\section{A. Geometry of the model and boundary conditions}

During the current research, an open area experiment was simulated to investigate air flow characteristics around a wind turbine. The test case for convergence studies is a two- dimensional representation of a single-bladed dragtype VAWT. Dimensions of the solution domain directly affect the simulation results: too short of a solution domain causes alternative solutions, which do not correspond to a real situation, or a solution domain which is too tight leads to incorrect impact of boundary conditions to the calculation results. Additional research on solution domain dimensions was conducted and the inlet boundary conditions were finally placed $6 D$ upstream from the rotor, the outlet $8 D$ downstream from the rotor and the free surface $3 D$ beside the rotor, where $D$ was the diameter of the turbine.
The boundary conditions are defined for four boundary types - inlet $I$, outlet $O$, free surface $F$ and rotor $R$, shown in Fig. 7. In the current research, different types of $k-\varepsilon$ turbulence models were used, so $k$ and $\varepsilon$ values have to be initialized at the inlet beside velocity $U$ and pressure $p$. Turbulence kinetic energy $k$ at the inlet is given by

$$
k_{i n l}=\frac{3}{2}(U I)^{2}
$$

where initial turbulence intensity $I$ is presumed as $8 \%$, and velocity $U$ as constant value.

The turbulence dissipation at the inlet is given by

$$
\varepsilon_{i n l}=c_{t} \frac{k_{i n l}^{\frac{3}{2}}}{l},
$$

where model coefficient $c_{t}=1$ and turbulence length scale $l$ is calculated from the characteristic length $L=2 \mathrm{~m}$ by equation $l=0.07 L$ [6]. The characteristic length is usually determined from the experiment, but the free surface is used instead of the wind tunnel's wall in this simulation, so the characteristic length is assumed as $2 \mathrm{~m}$. This assumption makes it possible to apply the coefficient $c_{t}=1$.

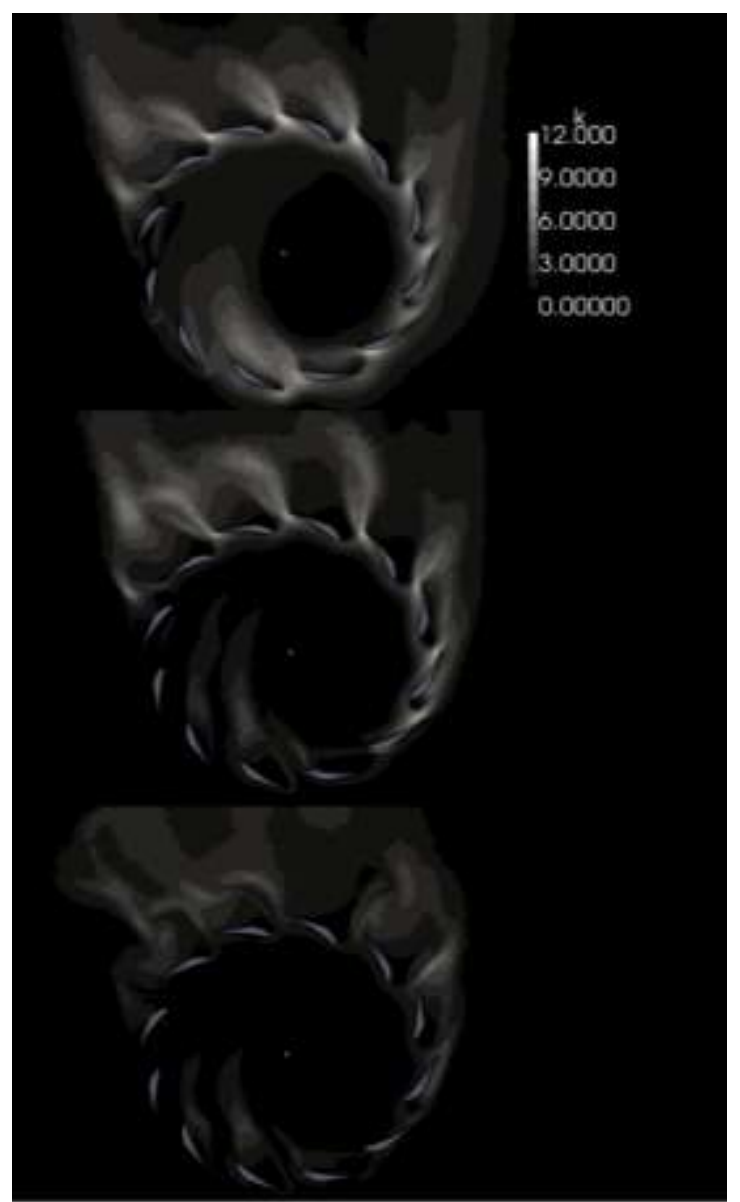

Fig. 4. Turbulence kinetic energy contour plot of Standard, Realizable and RNG $\mathrm{k}-\varepsilon$ turbulence models (presented in sequence of images). Zoomed in. 


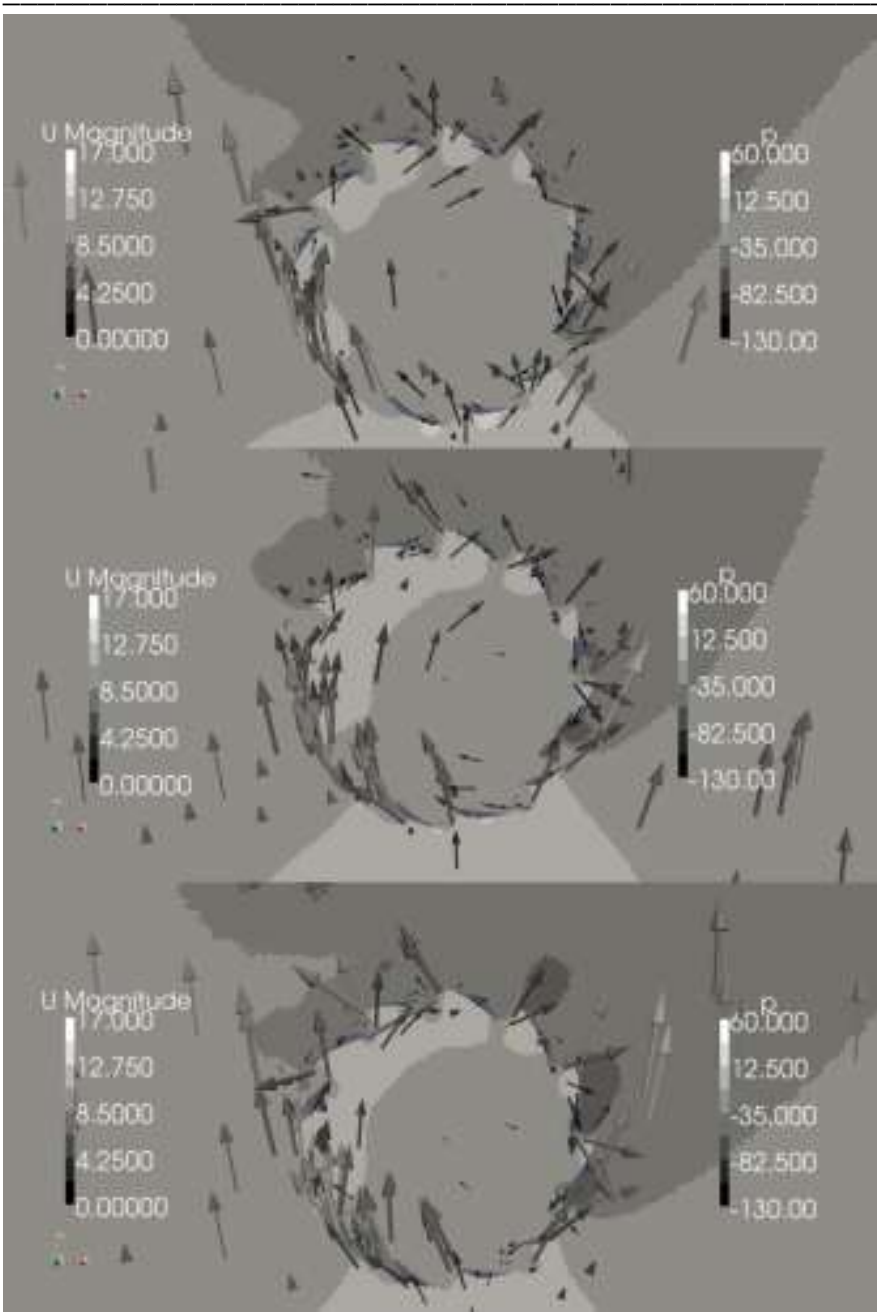

Fig. 5. Velocity vector and pressure contour plot of Standard, Realizable and RNG $\mathrm{k}-\varepsilon$ turbulence models (presented in sequence of images).

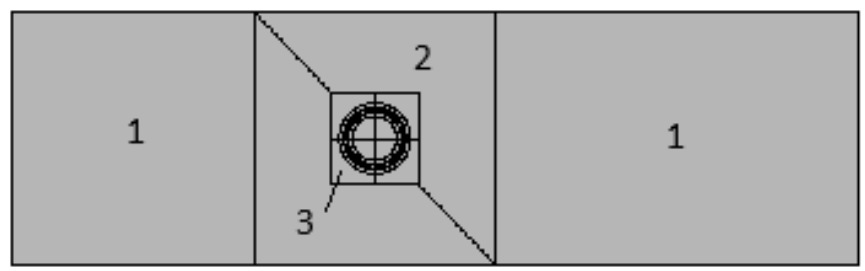

Fig. 6. Geometry of the model. Regions are marked by numbers.

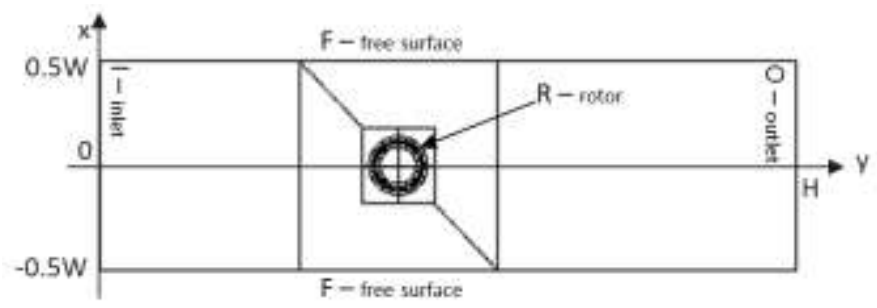

Fig. 7. Geometry of the model. Boundaries are marked by letters.

On the other boundaries, $k$ and $\varepsilon$ satisfies the following conditions:

$$
(\nabla k, n)=0,
$$

$$
(\nabla \varepsilon, n)=0
$$

where $n$ - normal and comma denotes scalar product.

The boundary conditions for velocity $U$ and pressure $p$ are summarised in Table II.

TABLE II

\begin{tabular}{|c|c|}
\hline Inlet & $\begin{array}{c}U=\text { const } \\
\left.\frac{\partial p}{\partial y}\right|_{\mathrm{y}=0}=0\end{array}$ \\
\hline Outlet & $\begin{array}{c}p=0 \\
\left.\frac{\partial U_{y}}{\partial y}\right|_{\mathrm{y}=0}=0 \\
U_{x}=U_{z}=0\end{array}$ \\
\hline Free surface & $\begin{array}{c}\left.\frac{\partial U_{y}}{\partial x}\right|_{\mathrm{x}}= \pm 0.5 \mathrm{~W} \\
U_{x}=U_{z}=0 \\
\left.\frac{\partial p}{\partial x}\right|_{\mathrm{x}= \pm 0.5 \mathrm{~W}}=0\end{array}$ \\
\hline Rotor & $\begin{array}{c}U=0 \\
(\nabla p, n)=0\end{array}$ \\
\hline
\end{tabular}

BOUNDARY CONDITIONS

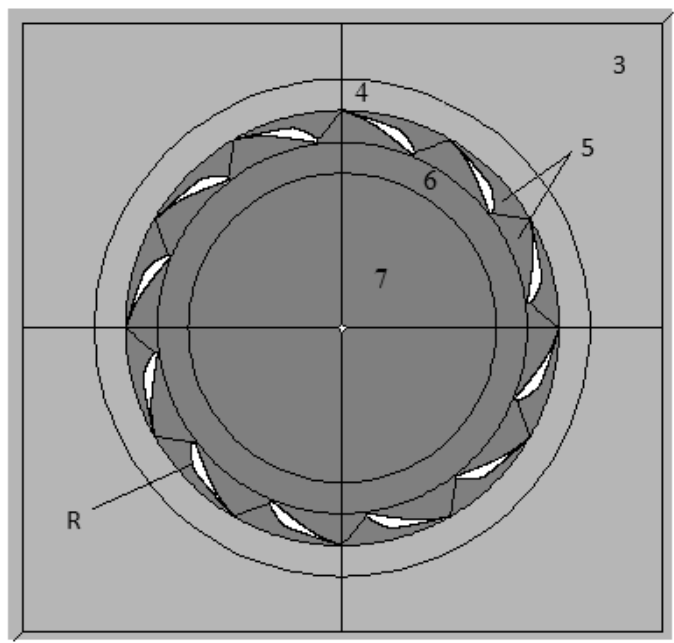

Fig. 8. Region 3 zoomed in.

\section{B. Simulation software}

The OpenFoam CFD toolbox solver for incompressible turbulent flow MRFSimpleFoam with several Reynolds average turbulence models was employed. MRFSimpleFoam uses a rotating frame technology to perform calculations. The model is split into a rotating and non-rotating part, the mesh is fixed, but Coriolis and centrifugal forces are applied to every new frame $[9,10]$. The rotating part is shaded dark gray in Fig. 8 and is rotated with angular velocity:

$$
\omega=2 \pi\left(\frac{R P M}{60}\right)
$$

where $R P M$ - revolutions per minute. Most of the studies were accomplished with $R P M=0$ and $R P M=60$. 


\section{Mesh properties}

Calculations are performed for two-dimensional unstructurized mesh, which consists of triangular cells. OpenFoam operates only in a 3 dimensional coordinate system, but a special boundary condition can be prescribed for the dimension which does not require a solution.

Solution converges to a stationary one by finer mesh refinement. No torque oscillations were observed for really fine meshes in the late iterations. However, this advantage takes high computational time, calculations ran for weeks in our case, and this is impractical and expensive. Authors decided to sacrifice exactness of solution in favour of more cases to be studied for trends, since slightly oscillating solutions on rougher meshes were rather similar to the ones on really fine mesh.

The division of the regions is shown in Fig. 6 and Fig. 8, but cell sizes in millimetres are summarised in Table III. The grid consists of 8 sub-grids for mesh size optimization. Region 1 consists of coarse mesh, because turbulence is isotropic in these areas, and there is no need for smaller refinement. The most refined region is located around blades of the turbine. The main interaction with air flow occurs around the blades and, thus, the part of the region at the edges of the blades has an even more refined cell than the region itself. Concentric ring type regions ensure sufficient cell skewness between coarser and denser refinement. Mesh can also be described by dimensionless quantity: mesh Reynolds number [11]:

$$
R e=\frac{\mathrm{u}_{\infty} \mathrm{L}}{v},
$$

where $u_{\infty}$ - infinite speed, $v$ - kinematic viscosity and $L$ characteristic length of the cell. For test meshes, Reynolds numbers for cells vary from $40 u_{\infty} \leq R e \leq 0.33 u_{\infty}$.

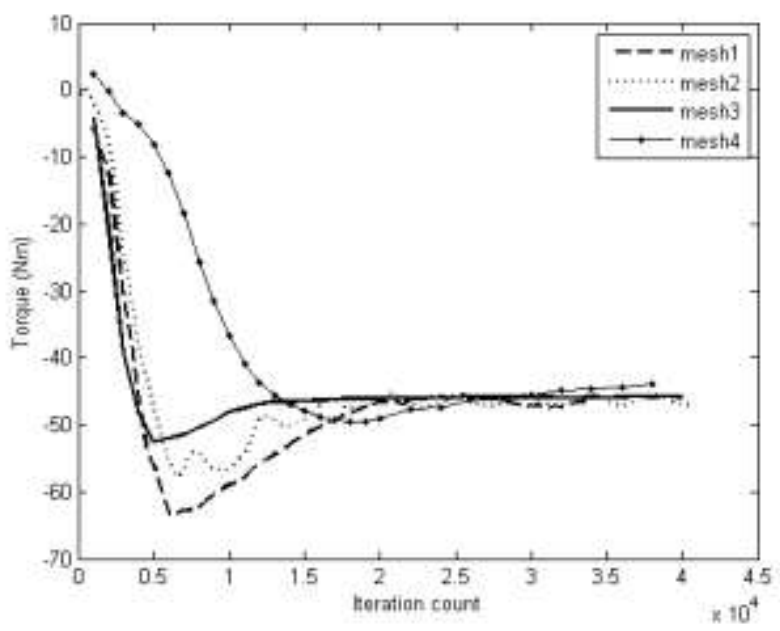

Fig. 9. Comparison of torque values between different mesh sizes during the calculations.

\section{Results}

Figure 9 shows values of torque during the calculations. A satisfying convergence with fluctuations approximately $10^{-3}$ is reached on mesh3. A more refined mesh 4 shows a more stable convergence, however it takes four times longer to converge. The hardware computational time for mesh3 (20 000 iterations) is three days and for mesh4 (20 iterations) six days. In other studies, mesh3 is used because of its computational speed. It is assumed that calculations, which converge on coarser mesh, will also converge on denser mesh.

TABLE III

MESH REFINEMENT (MM)

\begin{tabular}{|l|c|c|c|c|c|c|c|}
\hline $\begin{array}{l}\text { Mesh } \\
\text { No./region } \\
\text { No. }\end{array}$ & 1 & 2 & 3 & 4 & 5 & 6 & 7 \\
\hline mesh1 & 0.2 & 0.15 & 0.05 & 0.05 & $\begin{array}{c}0.025 \\
(0.01 *)\end{array}$ & 0.05 & 0.1 \\
\hline mesh2 & 0.4 & 0.4 & 0.1 & 0.05 & $\begin{array}{c}0.025 \\
(0.01 *)\end{array}$ & 0.05 & 0.1 \\
\hline mesh3 & 0.6 & 0.4 & 0.2 & 0.1 & $\begin{array}{c}0.025 \\
(0.01 *)\end{array}$ & 0.1 & 0.2 \\
\hline mesh4 & 0.3 & 0.2 & 0.1 & 0.05 & $\begin{array}{c}0.013 \\
(0.005 *)\end{array}$ & 0.05 & 0.1 \\
\hline
\end{tabular}

*at the edge of the blade.

\section{NUMERICAL APPROXIMATION SCHEMES FOR CONVECTIVE TERMS}

Numerical schemes transform continuous derivatives for finite points of grid and assign solutions for interpolation of values. It is well known that convective terms $u_{j} \frac{\partial u_{i}}{\partial x_{j}}$ make critical impact on simulations [4], so the results depend on the choice of the numerical scheme for convective terms. The free selection of interpolation schemes is available for the velocity $\mathrm{U}$ field. Four interpolation schemes were tested in the current research.

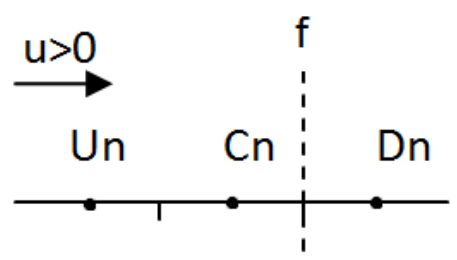

Fig. 10. A part of one - dimensional grid [11]

\section{A. Central differencing scheme}

According to the central differencing scheme, value of flux $\varphi$ at a face $\varphi_{f}$ is approximated as

$$
\varphi_{f}=0.5\left(\varphi_{C n}+\varphi_{D n}\right)
$$

where corresponding geometry is shown in Fig. 10 [6], [7].

Linear interpolation is used for convective terms approximation. This scheme has the second order accuracy, but it is unbounded, which means non-physical oscillations can appear. It also does not recognize the direction of the flow. 


\section{B. Limited linear differencing scheme}

Artificial oscillations can occur because of discontinuities and dramatic changes in the solution domain. The limited linear differencing scheme is a second order central differencing scheme with a value cropping condition which forbids the calculated value to differ from other points more than for the specified threshold [12].

\section{Upwind scheme}

The upwind scheme is a first order differencing scheme, which is dependent on the direction of the wind and introduces artificial viscosity of the mesh [12]. The value of flux $\varphi_{f}[6]$, [7] is evaluated as

$$
\varphi_{f}=U_{f}^{+} \varphi_{C n}+U_{f}^{-} \varphi_{D n},
$$

where $U_{f}^{+}=0.5\left(1+\frac{\left|U_{f}\right|}{U_{f}}\right)$ and $U_{f}^{-}=1-U_{f}^{+}$.

\section{Linear upwind scheme}

This scheme uses linear upwind differencing and, in the case of divergent terms, it behaves like a first/second order, bounded scheme [12]. This scheme can switch between two other schemes, depending on convergence. While calculated values between iterations show good convergence, the linear upwind scheme uses central differences and precision of second order, which results in precise, but sometimes unstable solution. In the regions where fast changes in the flow speed occur, linear upwind scheme uses upwind scheme, which is more stable, but less precise. In case of a mesh that is too coarse linear upwind scheme can switch over periodically and cause a jumping convergence graph.

\section{E. Results}

Torque graphics during the calculations in the Fig. 11 show the best convergence for upwind scheme. This scheme introduces artificial viscosity for the mesh to ensure convergence at the cost of reducing accuracy, so it is not recommended to use and is shown here only reference. Despite the issues regarding accuracy, the upwind scheme shows an upper limit for torque values and is suitable for $\mathrm{k}$ and $\varepsilon$ approximation (Fig. 13). The statistical characteristics of the results are shown in Table IV.

\section{TABLE IV}

STATISTICAL CHARACTERISTICS FOR CONVERGENCE

\begin{tabular}{|c|c|}
\hline Numerical scheme & Mean value of torque (after $\mathbf{2 0 ~} \mathbf{~ o 0 0}^{\text {th }}$ iteration) \\
\hline Central differencing & -0.1798 \\
\hline Limited linear & -0.1836 \\
\hline Upwind & -0.1868 \\
\hline Linear upwind & -0.1772 \\
\hline
\end{tabular}

The linear limited scheme differs from upwind by $-1.8 \%$, central differencing by $-3.8 \%$ and linear upwind by $5.2 \%$.

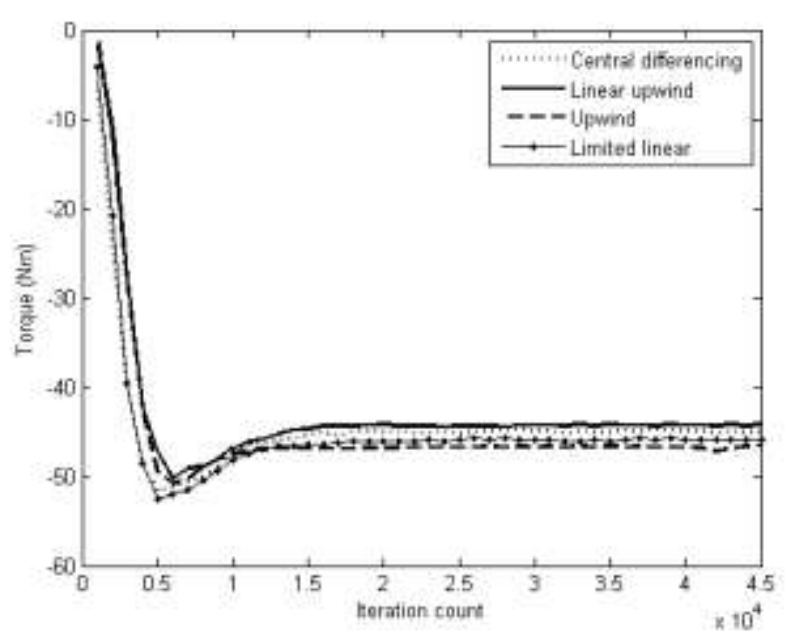

Fig. 11. Comparison of torque values between numerical approximation schemes during the calculations.

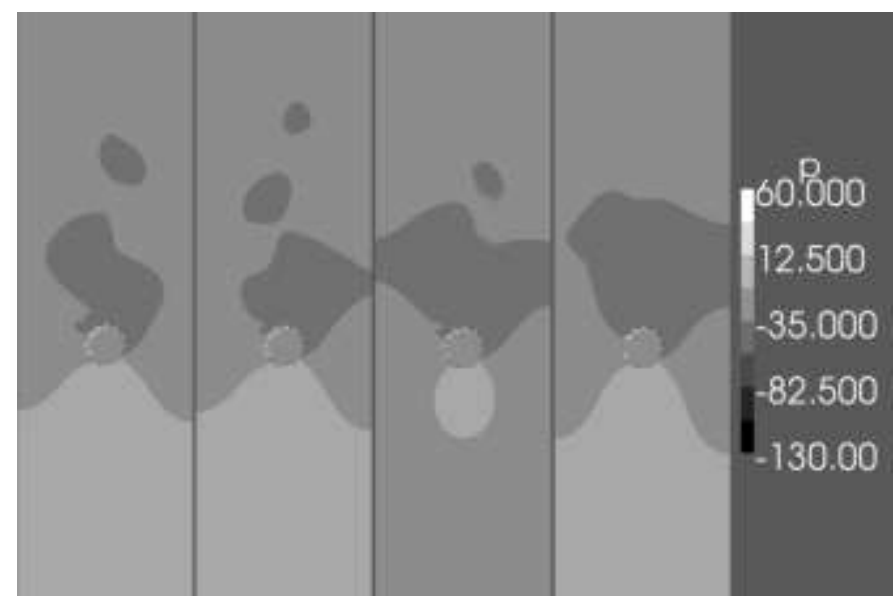

Fig. 12. Pressure contour plot of central differencing, limited linear, upwind and linear upwind schemes (presented in sequence of images).

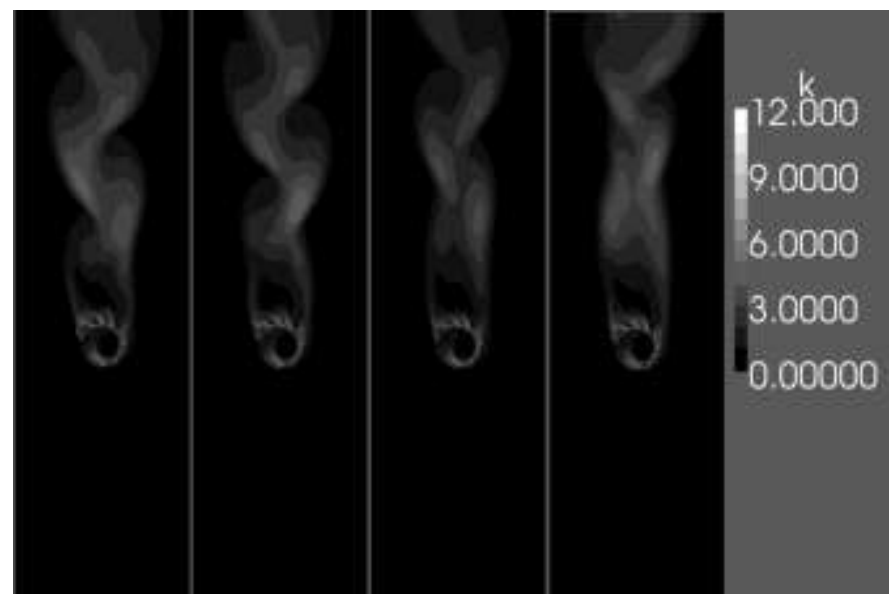

Fig. 13. Turbulence kinetic energy contour plot of central differencing, limited linear, upwind and linear upwind schemes (presented in sequence of images). 


\section{RELIABILITY OF RESULTS}

When examining torque graphics over time, they show great impact of parameters not only on convergence, but also on torque. There is no experimental data available on this turbine model so additional calculations have to be made to verify reliability as in the operational profile in Fig. 14. Operational profile corresponds to the general operational profile for a drag-type turbine. In order to evaluate the performance of the wind turbine precisely, a comparison between the calculated performance and that of a real wind tunnel would be necessary; however simulations can be used to provide relative comparison between different turbine designs.

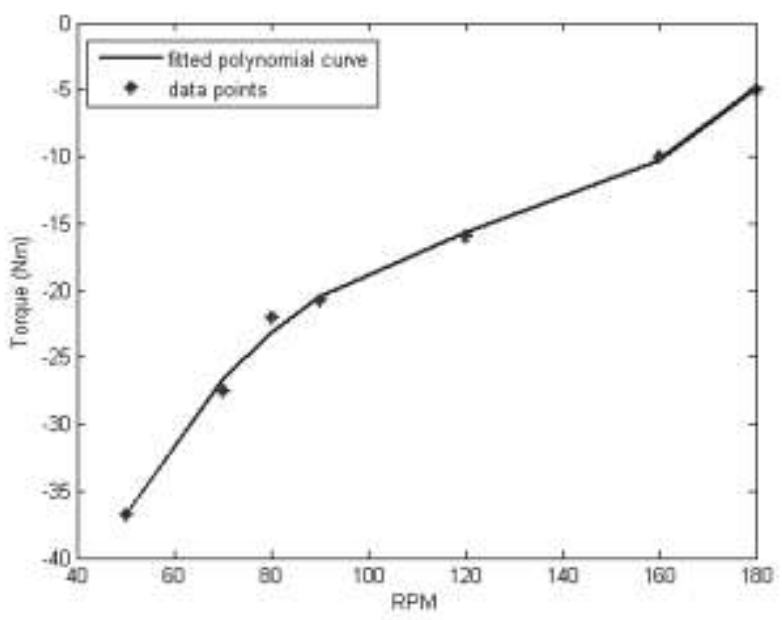

Fig. 14. Operational profile of the turbine at velocity $7 \mathrm{~m} / \mathrm{s}$.

\section{CONCLUSIONS}

The air flow over a vertical axis wind turbine was simulated by using an OpenFoam Toolbox to investigate critical parameters like mesh size, numerical approximations schemes and turbulence models to ensure convergence of the results.

Despite a simple, two-dimensional case, where turbine blades are fixed, it takes approximately five days to solve one case with mesh4 employing Intel ${ }^{\circledR}$ Xenon ${ }^{\circledR}$ CPU $3.00 \mathrm{GHz}$ 4 processor system with 4GB memory.

Satisfying convergence for mesh3 was reached after 15000 iterations, and it takes approximately 3 days to reach this.

Solution domain dimensions strongly impact results of the calculations: the region must be 7D (D - diameter of the turbine) wide to avoid incorrect interpretation of boundary conditions, and the outlet must be placed 8D downstream from the rotor in order to avoid alternative solutions. The maximum cell size at the edge of the blades is $0.33 u_{\infty}$ (cell Reynolds number).

Central differencing, limited linear, upwind and linear upwind numerical schemes were used for the approximation of convective terms. The upwind scheme provides an upper limit of torque values, however it is not recommended for precise calculations. The linear upwind scheme converges the best and differs from the central differencing scheme the least. Even finer mesh is recommended because the result, where the choice of schemes has no different impact on the torque, is not reached.

Turbulence models affect torque values even more than numerical schemes. The best convergence was reached by the standard $\mathrm{k}-\varepsilon$ model, while Realizable $\mathrm{k}-\varepsilon$ results were closer to the standard than the RNG results.

The RPM-Torque curve has an inflection point and the part after 180 RPM may not be reliable, due to the absence of convergence. Absence of the convergence in this region is still under investigation.

\section{REFERENCES}

1. Anderson D.J. Computational Fluid Dynamics. McGraw - Hill, 1995 , p. $47-49$

2. Blazek J. Computational Fluid Dynamics Principles and Applications. Elsevier Science, 2001, p. 229 - 232

3. Ferziger J.H., Peric M. Computational Methods for Fluid Dynamics. Springer Berlin Heidelberg; Auflage: 3rd, rev. ed., 2001, 437

4. Flecher C. A. J. Computational Techniques for Fluid Dynamics. Second edition. Springer - Verlag, 1991, p. 276 - 280

5. Pope S. B. Turbulent Flows. Cambridge University Press, 2005, p. $373-383$.

6. Versteeg H. K., Malalasekera W. An introduction to computational fluid dynamics. The finite volume method. Longman Scientific \& Technical, 1995, p. $67-76$.

7. Bounous O. Studies of the ERCOFTAC Conical Diffuser with OpenFOAM. Department of Applied Mechanics Chalmers University of Technology, Göteborg, 2008.

8. Karvinen A., Ahlstedt H. Comparison of turbulence models in case of three - dimensional diffuser, Tampere University of Technology, Tampere, 2008

9. Nillson H., Page M., Beaudoin M. et. al. The OpenFoam Turbomachinery working group, and conclusions from Turbomachineru session of the third OpenFoam workshop. In: IAHR

10. 24th Symposium on Hydraulic Machinery and Systems, 2008.

11. Petit O. OpenFOAM Project: Different ways to treat rotating geometries. 2007.

12. Tam C.K.W. and Kurbatskii K.A. Multi-Size-Mesh Multi-TimeStep Dispersion-Relation-Preserving Scheme for Multiple-Scales Aeroacoustics Problems. Department of Mathematics, Florida State University, Tallahassee, FL 32306-4510, USA

13. Fluent 6.3 documentation. Fluent Inc. September 2006.

14. OpenFoam documentation. Version 2.0.0. 16 th $^{\text {th }}$ June 2011 [Accessed 1.08.2011.]. Available: http://www.openfoam.com/docs/user/

\section{ACKNOWLEDGEMENTS}

\section{SATTEH No.}

2010/0189/2DP/2.1.1.2.0/10/APIA/VIAA/019 for financial support
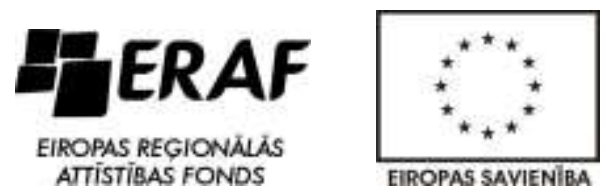

2. SIA Electric Rhino Run for partial financial support 


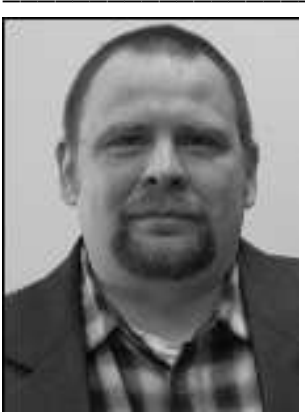

Normunds Jekabsons, PhD., Ventspils University College. Senior researcher in Ventspils International Radio astronomy Center (VSRC). Since 2010 head of high performance computing division in VSRC. The main research areas are Computer Fluid Dynamics, data processing and solid mechanics. Title of his doctoral thesis is "Mechanics of composites with fiber bundle meso-structure", from Lulea University of Technology (Sweden), year 2002. After finishing PhD studies in Sweden (19982002) Normunds Jekabsons has continued his professional work in Latvia. During last nine years participated in several local and international research and engineering

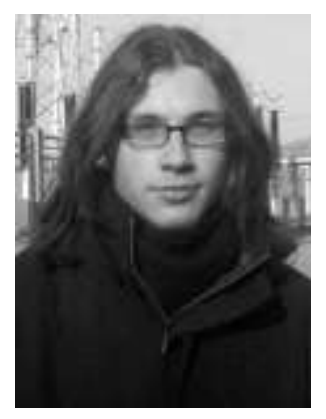

Agris Traskovs, M.Sc. IT, researcher, Ventspils University College. Currently participating research related to virtual instruments (National Instruments). The main research area is computer modelling. He has participated in Project "Vertical wind turbine model effectivness numerical modelling". Part of the results was presented in a local scientific conference. Master thesis "Parametrical studies of aerodynamic flow and power characteristics of a vertical axis wind turbine" was defended in Ventspils University College (2010). E-mail: agris.traskovs@ ventspils.gov.lv projects.

Address: Inzenieru 101A, Ventspils, LV-3601, Latvia

E-mail: normundsj@venta.lv

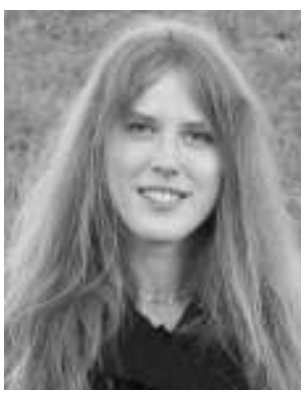

Linda Gulbe, B. sc. comp., specialist, Ventspils University College. Linda Gulbe has been participating in projects related to wind turbine options since 2010. The main field of research is computer simulation. The main areas of related projects are numerical simulations of operating efficiency of the wind turbine model and concepts of vertical axis wind turbine models. She has academic degree of Bachelor of Science in Computer Science and right now she continues her studies in Master study program.

E-mail: linda.gulbe@venta.lv

Linda Gulbe, Normunds Jēkabsons, Agris Traškovs. Parametriskie pētījumi vertikālās ass vēja turbīnu modelēšanai.

Samazinoties neatjaunojamās enerǵijas resursiem, kā arī palielinoties vides piesārṇojumam loǵiska ir doma pilnveidot vēja enerǵijas izmantošanu. Lai arī vēja enerǵijas izmantojuma zin̄ā līeres ir horizontālās ass vēja turbīnas, vertikālās ass vēja turbīnas iespējams pielāgot pilsētvidei un sarežğìtām vēja plūsmām. Vertikālās ass vēja turbīnas efektivitāte ir atkarīga no turbīnas dizaina. Vēja tuneḷu eksperimenti, kas parasti tiek veikti, lai pārbaudītu dizaina efektivitāti, ir dārgi. Tā vietā iespējams veikt skaitlisko modelēšanu. Lai arī skaitliskā modelēšana piedāvā daudz priekšrocību sal̄îzzinājumā ar reālu eksperimentu, to l̦oti ietekmē dažādi parametri kā režğga izmērs, skaitliskās aproksimācijas shēmas un turbulences modeḷi. Pētijjuma mērkis ir noskaidrot šo parametru ietekmi uz aprēkinu konverğenci. Simulācijas tika veiktas izmantojot Openfoam instrumentārija solveri nesaspiežamām plūsmām MRFSimpleFoam, kurš izmanto rotējošā kadra tehnolog̣iju. Parametru pētījumi tikai veikti fiksējot pārējos parametrus un mainot tikai pētāmo parametru, piemēram, turbulences modeli. Rezultātā tika atrasts optimāls režğa smalcinājums, skaitliskā aproksimācijas shēma un turbulences modelis, kas nodrošina aprēḳinu konverǵenci. Veicot skaitlisko shēmu pētījumus vislabāk konverǵēja pretvēja shēma, taču tā ievieš mākslīgu režğg viskozitāti, lai nodrošinātu labu konverǵenci uz precizitātes rẹkina. Š̉ iemesla dēl kā piemērotākā shēma tika izvēlēta limitētā centrālo diferenču shēma. Standarta $\mathrm{k}-\varepsilon$ modelis konkrētajai geometrijai un režğa smalcinājumam uzrādīja vislabāko konverǵenci. RNG un Realizable $\mathrm{k}-\varepsilon$ modẹi ir precīzāki, taču tiem nepieciešams smalkāks režğis par testos izmantoto un RNG modeḷa gadījumā arī plašāks apgabals ap turbīnu. 